\title{
Pregeometry on the subsets of Jonsson theory's semantic model
}

\begin{abstract}
One of the interesting achievements among investigations from modern model theory is the implement of local properties of the geometry of strongly minimal sets. In E. Hrushovski have proved remarkable results under this ideas and this one had impacted an essential infuence for development of methods and ideas of research for global properties of structures. These new model-theoretical features and approvals play an important role in E. Hrushovski's proof of the Mordell-Lang Conjecture for function fields.

In this article, we are trying to redefine the basic concepts of the above mentioned ideas on the formul subsets of some extentional-closed model for some fixed Jonsson theory. With the help of new concepts in the frame of Jonssoness features, pregeometry is given on all subsets of Jonsson theory's semantic model. Minimal structures and, correspondingly, pregeometry and geometry of minimal structures are determined. We consider the concepts of dimension, independence, and basis in the Jonsson strongly minimal structures for Jonsson theories.
\end{abstract}

Keywords: Jonsson theory, Jonsson set, semantic model, Jonsson minimal structure, Jonsson pregeometry, Jonsson dimension, Jonsson basis, Jonsson independence, modularity.

In the paper [1,2] strongly minimal Jonsson sets were studied. A natural generalization will be a consideration of Jonsson analogs of strongly minimal arbitrary subsets of semantic model of some fixed Jonsson theory.

In order that we could transfer from the apparatus of Model theory of developed for complete theories the basic concepts connected with the concept of strongly minimal for fixed formula subsets of semantic model of the above Jonsson theory, we need the semantic model to be saturated in its power, that is, the theory must be perfect. We note that similar approaches to the work with the transfer of basic model-theoretic concepts for some fixed Jonsson theory and its semantic model were considered in the following works [3-5].

We recall the necessary definitions. We will assume everywhere that the language is always countable.

Definition 1 [6]. A theory $\mathrm{T}$ is called Jonsson if:

1) The theory $\mathrm{T}$ has an infinite models;

2) The theory $\mathrm{T}$ is inductive;

3) The theory $\mathrm{T}$ has the joint embedding property (JEP);

4) The theory $\mathrm{T}$ has the amalgamation property (AP).

Further, throughout this article, all considered theories will be an existential complete perfect Jonsson theory in a countable language $\mathcal{L}$.

In this paper, we redefine the basic concepts connected with strongly minimal for complete theories in the framework of the study of some Jonsson theory. All main definitions belong to A. Yeshkeyev and they are taken from the above sources. All results that are given without proof also belong to A. Yeshkeyev and they can be extracted from $[2]$.

Let $\mathcal{M}$ be some an existentially closed submodel of semantic model for fixed Jonsson theory in the language $\mathcal{L}, \phi(\bar{v})$ is an $\mathcal{L}_{M}$-formula, we will let $\phi(\mathcal{M})$ denote the elements of $M$ that satisfy $\phi$.

Definition 2. Let $D \subseteq M^{n}$ be an infinite $\Delta$-definable set, where $\Delta \subseteq \mathcal{L}$. As a rule, throughout this article under $\Delta$ we shall consider the set of all existential formulas of the given language. We say that a set $\mathrm{D}$ is Jonsson minimal in $\mathcal{M}$ if for any $\Delta$-definable $Y \subseteq D$ either $Y$ is finite or $D \backslash Y$ is finite.

If $\phi(\bar{v}, \bar{a})$ is the formula that defines $D$, then we also say that $\phi(\bar{v}, \bar{a})$ is Jonsson minimal.

We say that $D$ and $\phi$ are Jonsson strongly minimal if $\phi$ is Jonsson minimal in any existentially closed extension $\mathcal{N}$ of $\mathcal{M}$.

We say that a theory $\mathrm{T}$ is Jonsson strongly minimal if the formula $v=v$ is Jonsson strongly minimal (i.e., if $\mathcal{M} \in \operatorname{ModE}_{T}$ then $M$ is Jonsson strongly minimal).

Let $\mathcal{M}$ be some an existentially closed submodel of semantic model for fixed Jonsson theory in the language $\mathcal{L}$ and $D \subseteq M$ be Jonsson strongly minimal. 
We will consider $\operatorname{acl}_{D}$, the algebraic closure relation restricted to $D$. Recall that $b$ is Jonsson algebraic over $A$ if there is a formula $\phi(x, \bar{a}) \in \Delta$ with $\bar{a} \in A$ such that $\phi(\mathcal{M}, \bar{a})$ is finite.

For $A \subseteq D$, we let $\operatorname{acl}_{D}(A)=\{b \in D: b$ is Jonsson algebraic over $A\}$.

The following properties of Jonsson algebraic closure are true for any subset D of semantic model for theory T.

Lemma 1.

1) $\operatorname{acl}(\operatorname{acl}(A))=\operatorname{acl}(A) \supseteq A$.

2) If $A \subseteq B$, then $\operatorname{acl}(\mathrm{A}) \subseteq \operatorname{acl}(\mathrm{B})$.

3) If $a \in \operatorname{acl}(\mathrm{A})$, then $a \in \operatorname{acl}\left(\mathrm{A}_{0}\right)$ for some finite $\mathrm{A}_{0} \subseteq A$.

Lemma 2 (Exchange Principle) Suppose that $\mathrm{D} \subset \mathrm{M}$ is Jonsson strongly minimal, $\mathrm{A} \subseteq \mathrm{D}$, and a, $\mathrm{b} \in \mathrm{D}$. If $\mathrm{a} \in \operatorname{acl}(A U\{b\}) \backslash \operatorname{acl}(A)$, then $\mathrm{b} \in \operatorname{acl}(A \cup\{a\})$.

In any Jonsson strongly minimal set, we can define a notion of independence. We fix $\mathcal{M} \in \operatorname{Mod} E_{T}$ and $\mathrm{D}$ is Jonsson strongly minimal set in $\mathcal{M}$.

Definition 3. We say that $\mathrm{A} \subseteq \mathrm{D}$ is Jonsson independent if a $\in \operatorname{acl}(A \backslash\{a\})$ for all a $\in A$. If $C \subset D$, we say that $\mathrm{A}$ is Jonsson independent over $\mathrm{C}$ if $\mathrm{a} \notin \operatorname{acl}(C \mathrm{U}(A \backslash\{a\}))$ for all a $\in \mathrm{A}$.

It is turn out that cardinality is the only one opportunity to distinguish independent subsets of D.

Definition 4. We say that $A$ is a Jonsson basis for $Y \subseteq D$ if $A \subseteq Y$ is Jonsson independent and $\operatorname{acl}(A)=\operatorname{acl}(Y)$.

Clearly, any maximal Jonsson independent subset of $Y$ is a Jonsson basis for $Y$.

Lemma 3. Let $A, B \subseteq D$ be Jonsson independent with $A \subseteq$ acl $(B)$.

1) Suppose that $A_{0} \subseteq A, B_{0} \subseteq B, A_{0} \cup B_{0}$ is Jonsson basis for $a c l(B)$ and $a \in A \backslash A_{0}$. Then, there is $b \in B_{0}$ such that $A_{0} \cup\{a\} \cup\left(B_{0} \backslash\{b\}\right)$ is Jonsson basis for $\operatorname{acl}(B)$.

2) $|A| \leq|B|$.

3) If $A$ and $B$ are Jonsson bases for $Y \subseteq D$, then $|A|=|B|$.

Definition 5. If $Y \subseteq D$, then the Jonsson dimension of $Y$ is the cardinality of a Jonsson basis for $Y$.

We denote the Jonsson dimension of $Y$ through $\operatorname{Jdim}(Y)$.

Note that if $D$ is uncountable, then $\operatorname{Jdim}(D)=|D|$ because our language is countable and $\operatorname{acl}(A)$ is countable for any countable $A \subseteq D$.

For Jonsson strongly minimal theories, every model is determined up to isomorphism by its Jonsson dimension.

Theorem 1. Suppose $T$ is a Jonsson strongly minimal theory.

$\mathcal{M}, \mathcal{N} \in \operatorname{Mod} E_{T}$ then $\mathcal{M} \cong \mathcal{N}$ if and only if $\operatorname{Jdim}(M)=\operatorname{Jdim}(N)$.

Corollary 1. If $T$ is a Jonsson strongly minimal theory, then $T^{*}$ is $\kappa$-categorical for $\kappa \geq \aleph_{0}$ and $I\left(T, \aleph_{0}\right) \leq \aleph_{0}$, where $T^{*}$ is the center of $T$ and $I\left(T, \aleph_{0}\right)$ denote the number of existentially closed countable models of $T$.

Analogously to the Baldwin-Lachlan result, we obtain the following theorem.

Theorem 2. If $T^{*}$ is perfect existentially complete Jonsson theory, then $I\left(T, \aleph_{0}\right)=\aleph_{0}$.

In this article, we will use Jonsson strongly minimal sets and consider some properties of combinatorial geometry of algebraic closure.

It is well known that in the proof of Morley's theorem on uncountable categoricity, the properties of an algebraic closure on strongly minimal sets are used in an essential way. In this article, we turn to Jonsson strongly minimal sets and with their help we study the combinatorial geometry of algebraic closure.

We give the following definitions.

Definition 6 . Let $X$ be subset of semantic model of fixed Jonsson theory and let cl :P(X) $\longrightarrow \mathcal{P}(X)$ be an operator on the power set of $X$. We say that $(X, c l)$ is a Jonsson pregeometry if the following conditions are satisfied.

1. If $A \subseteq X$, then $A \subseteq \operatorname{cl}(A)$ and $\operatorname{cl}(\operatorname{cl}(A))=\operatorname{cl}(A)$.

2. If $A \subseteq B \subseteq X$, then $\operatorname{cl}(A) \subseteq \operatorname{cl}(B)$.

3. (Exchange) $A \subseteq X, a, b \in X$, and $a \in \operatorname{cl}(A \cup\{b\})$, then $a \in \operatorname{cl}(A) b \in \operatorname{cl}(A \cup\{a\}$.

4. (Finite character) If $A \subseteq X$ and $a \in \operatorname{cl}(A)$, then there is a finite $A_{0} \subseteq A$ such that $a \in \operatorname{cl}\left(A_{0}\right)$.

We say that $A \subseteq X$ is closed if $c l(A)=A$.

We may notice (By Lemmas 1 and 2) that if $D$ is Jonsson strongly minimal, we can specify a Jonsson pregeometry by defining $\operatorname{cl}(A)=\operatorname{acl}(A) \cap D$ for $A \subseteq D$. We can generalize basic ideas about independence and dimension from Jonsson strongly minimal sets to arbitrary Jonsson pregeometries. 
Definition \%. If $(X, c l)$ is a Jonsson pregeometry, we say that $A$ is Jonsson independent if $a \notin c l(A \backslash\{a\})$ for all $a \in A$ and that $B$ is a $J$-basis for $Y$ if $B \subseteq Y$ is J-independent and $Y \subseteq \operatorname{acl}(B)$. The natural generalization of Lemma 3 is true for all $J$-pregeometries.

Lemma 4. If $(X, c l)$ is a $J$-pregeometry, $Y \subseteq X, B_{1}, B_{2} \subseteq Y$, and each $B_{i}$ is a $J$-basis for $Y$, then $\left|B_{1}\right|=\left|B_{2}\right|$.

We call $\left|B_{i}\right|$ the $J$-dimension of $Y$ and write $J \operatorname{dim}(Y)=\left|B_{i}\right|$.

If $A \subseteq X$, we also consider the localization $\operatorname{cl}_{A}(B)=\operatorname{cl}(A \cup B)$.

Lemma 5. If $(X, c l)$ is a $J$-pregeometry, then $\left(X, c l_{A}\right)$ is a $J$-pregeometry.

If $(X, c l)$ is a $J$-pregeometry, we say that $Y \subseteq X$ is $J$-independent over $A$ if $Y$ is $J$-independent in $\left(X, c l_{A}\right)$. We let $\operatorname{Jdim}(Y / A)$ be the $J$-dimension of $Y$ in the localization $\left(X, c l_{A}\right)$. We call $J \operatorname{dim}(Y / A)$ the $J$-dimension of $Y$ over $A$.

Definition 8 . We say that a J-pregeometry $(X, c l)$ is a J-geometry if $\operatorname{cl}(\oslash)=\oslash$ and $c l(\{x\})=\{x\}$ for any $x \in X$.

If $(X, c l)$ is a J-pregeometry, then we can naturally define a J-geometry. Let $X_{0}=X / \operatorname{cl}(\oslash)$. Consider the relation $\sim$ on $X_{0}$ given by $a \sim b$ if and only if $\operatorname{cl}(\{a\})=\operatorname{cl}(\{b\})$. By exchange, $\sim$ is an equivalence relation. Let $\hat{X}$ be $X_{0} / \sim$. Define $\hat{c l}$ on $\hat{X}$ by $\hat{c l}(A / \sim)=\{b / \sim: b \in \operatorname{cl}(A)\}$

Lemma 6 . If $(X, c l)$ is a J-pregeometry, then $(\hat{X}, \hat{c l})$ is a J-geometry.

We distinguish some properties of J-pregeometries that will play an important role.

Definition 9. Let $(X, c l)$ be J-pregeometry. We say that $(X, c l)$ is trivial if $c l(A)=\cup_{a \in A} c l(\{a\})$ for any $A \subseteq X$. We say that $(X, c l)$ is modular if for any finite-dimensional closed $A, B \subseteq X$

$$
J \operatorname{dim}(A \cup B)=J \operatorname{dim}(A)+J \operatorname{dim}(B)-J \operatorname{dim}(A \cap B) .
$$

We say that $(X, c l)$ is locally modular if $\left(X, c l_{a}\right)$ is modular for some $a \in X$.

Theorem 3. Let $(X, c l)$ be J- pregeometry. The following are equivalent.

1. $(X, c l)$ is modular.

2. If $A \subseteq X$ is closed and nonempty, $b \in X$, and $x \in \operatorname{cl}(A, b)$, then there is $a \in A$ such that $x \in \operatorname{cl}(a, b)$.

3. If $A, B \subseteq X$ are closed and nonempty, and $x \in \operatorname{cl}(A, B)$, then there are $a \in A$ and $b \in B$ such that $x \in \operatorname{cl}(a, b)$.

Proof. Let us prove 1$) \Rightarrow 2$ ). By the definition of the closure, we conclude that $J \operatorname{dim} A$ is finite. There are two cases $x \in \operatorname{cl}(b)$ and $x \notin c l(b)$. The case $x \in \operatorname{cl}(b)$ is proved trivially. It is sufficient for us to consider the case when $x \notin \operatorname{cl}(b)$. As consequence, from definition of modularity $J \operatorname{dim}(A, b, x)=J \operatorname{dim} A+$ $+J \operatorname{dim}(b, x)-J \operatorname{dim}(A \cap c l(b, x))$ and $J \operatorname{dim}(A, b, x)=J \operatorname{dim}(A, b)=J \operatorname{dim} A+J \operatorname{dim} b-J \operatorname{dim}(A \cap c l(b))$. Since $J \operatorname{dim}(b, x)=J \operatorname{dim}(b)+1$, then there exists $a \in A$ such that $a \in \operatorname{cl}(b, x) \backslash \operatorname{cl}(b)$. Consequently, by the Exchange Principle, we obtain $x \in \operatorname{cl}(b, a)$.

Let us prove 2$) \Rightarrow 3$ ). Without loss of generality, we consider case, $J \operatorname{dim} A<\omega$ and $J \operatorname{dim} B<\omega$. Further we will prove by induction on $J \operatorname{dim} A$. If $J \operatorname{dim} A$ is zero, then the condition 3$)$ is satisfied. Let $A=\operatorname{cl}\left(A_{0}, a\right)$ where $J \operatorname{dim} A=J \operatorname{dim} A-1$. Hence $x \in \operatorname{cl}\left(A_{0}, B, a\right)$. From 2) it follows that, there is $c \in \operatorname{cl}\left(A_{0}, B\right)$ such that $x \in \operatorname{cl}(c, a)$. By induction, there is $a_{0} \in A_{0}$ and $b \in B$ such that $c \in \operatorname{cl}\left(c_{0}, b\right)$. Continuing further, by condition 2) there is $a^{*} \in \operatorname{cl}\left(a_{0}, a\right) \subseteq A$ such that $x \in \operatorname{cl}(b, a)$.

Let us prove 3$) \Rightarrow 1)$. We may assume that $A, B \subseteq X$ are finite-dimensional and closed. We will show condition 1) by induction on $J \operatorname{dim} A$. If $J \operatorname{dim} A=0$, then we are done. Assume that $\left.A=\operatorname{cl}\left(A_{0}, a\right)\right)$, where $J \operatorname{dim} A_{0}=J \operatorname{dim} A-1$ and we suppose, by induction, that

$$
J \operatorname{dim}\left(A_{0}, B\right)=J \operatorname{dim} A_{0}+J \operatorname{dim} B-J \operatorname{dim}\left(A_{0} \cap B\right) .
$$

First of all, suppose that $a \in \operatorname{cl}\left(A_{0}, B\right)$. Hence $J \operatorname{dim}\left(A_{0}, B\right)=J \operatorname{dim}(A, B)$ and, since $a \notin A_{0}$, $J \operatorname{dim} A=J \operatorname{dim} A_{0}+1$. Since $a \in \operatorname{cl}\left(A_{0}, B\right)$, then by 3$)$ there is $a_{0} \in A_{0}$ and $b \in B$ such that $a \in \operatorname{cl}\left(a_{0}, b\right)$. Because $a \notin \operatorname{cl}\left(a_{0}\right)$, by the Exchange Principle, $b \in \operatorname{cl}\left(a, a_{0}\right)$. So $b \in A$. But $b \notin A_{0}$, because otherwise $a \in A_{0}$. Therefore, $J \operatorname{dim}(A \cap B)=J \operatorname{dim}\left(A_{0}, B\right)+1$, as we would like.

Further, assume that $a \notin \operatorname{cl}\left(A_{0}, B\right)$. We must show that $A \cap B=A_{0} \cap B$. Suppose that $b \in B$ and $b \in \operatorname{cl}\left(A_{0}, a\right) \backslash \operatorname{cl}\left(A_{0}\right)$. Then, by the Exchange Principle, $a \in \operatorname{cl}\left(A_{0}, b\right)$, we have obtained a contradiction.

All undefined concepts related to Jonsson theory can be found in [7]. 


\title{
References
}

1 Hrushovski E. The Mordell-Lang conjecture for function fields / E.Hrushovski // Journal AMS. - 1996. - 9. - P. 667-690.

2 Yeshkeyev A.R. Strongly minimal Jonsson sets and their properties 47-52 / A.R. Yeshkeyev // Bulleten of the Karaganda University. Mathematics series. - 2015. - № 4(80). - P. 47-52.

3 Yeshkeyev A.R. On Jonsson stability and some of its generalizations / A.R. Yeshkeyev // Journal of Mathematical Sciences. - 2010. - Vol. 166. - No. 5. - P. 646-654.

4 Yeshkeyev A.R. The structure of lattices of positive existential formulae of ( $\Delta$ - PJ)-theories / A.R. Yeshkeyev // Scienceasia. - 2013. - Vol. 39. - P. 19-24

5 Ешкеев A.P. JSp-косемантичность и JSB свойство абелевых групп / A.P. Ешкеев, О.И. Ульбрихт // Сибирские электронные математические известия. - 2016. - Т. 13. - С. 861-874.

6 Справочная книга по математической логике: в 4 ч. - Ч. 1. Теория моделей / под ред. Дж.Барвайса; пер. с англ. - М.: Наука; Гл. ред. физ.-мат. лит., 1982. - 126 с.

7 Ешкеев А.Р. Йонсоновские теории и их классы моделей: монография / А.Р. Ешкеев, М.Т. Касыметова. - Караганда: Изд-во КарГУ, 2016. - 370 с.

\section{М.Т. Касыметова}

\section{Йонсондық теорияның семантикалық моделінің ішкі жиындарындағы прегеометрия}

\begin{abstract}
Қазіргі модельдер теориясының нәтижелері арасындағы ең қызықты жетістіктерінің біріне қатты минималды жиындардың геометриясының локалды қасиеттерін жүзеге асыру жатады. Осы идеяларға қатысты жұмысында Э. Хрущовскийдың тамаша нәтижелерге ие болды. Олар құрылымдардың ғаламды қасиеттерін зерттеу үшін әдістердің және идеялардың дамуына елеулі ықпал етеді. Бұл теория-модельдік ерекшеліктері мен мәлімдемелері функциялар өрістер үшін Хрущовскийдың Морделл-Ланг гипотезасын дәлелдеуінде маңызды рөл атқарады. Мақалада автор жоғарыда көрсетілген идеялардың негізгі ұғымдарын кейбір бекітілген йонсондық теория үшін экзистенционалдытұйық модельдерінің формулалық ішкі жиындары арқылы анықтауға тырысты. Сонымен қатар жаңа ұғымдар көмегімен ерекшеліктердің йонсондылылығының аясында йонсондық теорияның семантикалық моделінің барлық ішкі жиындарында прегеометрия ұғымы берілді. Минималды құрылымдар және сәйкесінше прегеометрия және минималды структуралардың геометриясы анықталды. Йонсондық теориялар үшін йонсондық қатты минималды құрылымдарда өлшемділік, тәуелсіздік және базис ұғымдары қарастырылды.
\end{abstract}

Kiлm сөздер: йонсондық теория, йонсондық жиын, семантикалық модель, йонсондық минималды құрылым, йонсондық прегеометрия, йонсондық өлшем, йонсондық базис, йонсондық тәуелсіздік, модулярлық.

\section{М.Т. Касыметова}

\section{Предгеометрия на подмножествах семантической модели йонсоновской теории}

\footnotetext{
Одним из интересных достижений среди исследований современной теории моделей является реализация локальных свойств геометрии сильно минимальных множеств. В работе Э. Хрущовского показаны замечательные результаты по этим идеям, и это оказало существенное влияние на разработку методов и идей исследования глобальных свойств структур. Эти новые теоретико-модельные особенности и утверждения играют важную роль в доказательстве Э. Хрущовского гипотезы Морделла-Ланга для функций полей. В этой статье мы пытаемся переопределить основные понятия упомянутых выше идей на формульных подмножествах некоторой экзистенциально-замкнутой модели для некоторой фиксированной йонсоновской теории. С помощью новых понятий в рамках особенностей йонсоновости
} 
предгеометрия дается на всех подмножествах семантической модели йонсоновской теории. Определены минимальные структуры и, соответственно, предгеометрия, и геометрия минимальных структур. Рассмотрены понятия размерности, независимости и базиса в йонсоновских сильно минимальных структурах для йонсоновских теорий.

Ключевые слова: йонсоновская теория, йонсоновское множество, семантическая модель, йонсоновская минимальная структура, йонсоновская предгеометрия, йонсоновская размерность, йонсоновский базис, йонсоновская независимость, модулярность.

\section{References}

1 Hrushovski, E. (1996). The Mordell-Lang conjecture for function fields. Journal AMS-9, 667-690.

2 Yeshkeyev, A.R. (2015). Strongly minimal Jonsson sets and their properties. Bulleten of the Karaganda University. Mathematics series, No 4(80), 47-52.

3 Yeshkeyev, A.R. (2010). On Jonsson stability and some of its generalizations. Journal of Mathematical Sciences, Vol. 166, 5, 646-654.

4 Yeshkeyev, A.R. (2013). The structure of lattices of positive existential formulae of ( $\Delta$ - PJ)-theories. Scienceasia, Vol. 39, 19-24.

5 Yeshkeyev, A.R., \& Ulbrikht, O.I. (2016). JSp-kosemantichnost i JSB svoistvo abelevykh hrupp [JSpcosemanticness and JSB property of Abelian groups]. Sibirskie elektronnye matematicheskie izvestiia Siberian Electronic Mathematical Reports, Vol. 13, 861-874 [in Russian].

6 Barwaise, J. (1982). Spravochnaia kniha po matematicheskoi lohike. Teoriia modeley [Handbook of mathematical logic. Model theory]. (Part 1-4, Part 1). Moscow: Nauka [in Russian].

7 Yeshkeyev, A.R, \& Kassymetova, M.T. (2016). Yonsonovskie teorii i ikh klassy modeley [Jonsson theories and their classes of models]. Karaganda: KarHU [in Russian]. 